\title{
High adiposity is associated cross-sectionally with low self-concept and body size dissatisfaction among indigenous Cree schoolchildren in Canada
}

Noreen Dianne Willows ${ }^{1 *}$, Denise Ridley ${ }^{2}$, Kim D Raine $^{2,3}$ and Katerina Maximova ${ }^{3}$

\begin{abstract}
Background: Obesity and mental health problems are prevalent among indigenous children in Canada and the United States. In this cross-sectional study the associations between adiposity and body size satisfaction, body image and self-concept were examined in indigenous children in grades four to six living in Cree communities in the Province of Quebec (Canada).
\end{abstract}

Methods: Weight status and body mass index (BMI) z-scores were derived from children's measured height and weight using the World Health Organization growth reference. Multivariate regression models that included child's age and sex were used to assess the association between (a) weight status and physical appearance satisfaction using pictorial and verbal body rating measures in 202 of 263 children, and (b) BMI z-score and self-concept measured using the Piers-Harris Children's Self-Concept Scale in a subset of 78 children.

Results: Children (10.67 \pm 0.98 years) were predominantly overweight (28.2\%) or obese (45.0\%). Many (40.0\%) children had low global self-concept indicating that they had serious doubts about their self-worth and lacked confidence. About one-third (34.7\%) of children did not like the way they looked and $46.3 \%$ scored low on the physical appearance and attributes domain of self-concept indicating poor self-esteem in relation to their body image and physical strength, feeling unattractive, or being bothered by specific aspects of their physical appearance. Compared to normal weight children, overweight and obese children were more likely to desire being smaller ( $\mathrm{OR}=4.3$ and 19.8, respectively), say their body size was too big ( $\mathrm{OR}=7.7$ and 30.6, respectively) and not liking the way they looked ( $\mathrm{OR}=2.4$ and 7.8, respectively). Higher BMI $z$-score was associated with lower scores for global self-concept $(\beta=-1.3)$, intellectual and school status $(\beta=-1.5)$ and physical appearance and attributes ( $\beta=-1.3$ ) indicating negative self-evaluations in these areas. Despite comparable weight status to boys, girls were more likely to have lower scores for global self-concept ( $\beta=-3.8)$, physical appearance and attributes $(\beta=-4.2)$, desiring to be smaller $(\mathrm{OR}=4.3)$ and not liking the way they looked $(\mathrm{OR}=2.3)$.

Conclusions: The psychosocial correlates of obesity are important considerations for indigenous children, particularly girls, given that poor self-concept and body size dissatisfaction negatively impact mental and emotional qualities of life.

Keywords: Obesity, Body image, Self-esteem, Self-concept, Canada, First nations, Aboriginal, Indigenous, Child, Indians, North American

\footnotetext{
* Correspondence: noreen.willows@ualberta.ca

${ }^{1}$ Department of Agricultural, Food and Nutritional Science, University of Alberta, Edmonton, Canada

Full list of author information is available at the end of the article
} 


\section{Background}

Obesity and mental health problems including depression are highly prevalent among indigenous children in Canada (i.e., First Nations, Inuit, and Métis) and the United States (i.e., American Indians and Alaska Natives) [1-4]. Among indigenous children, as in the general pediatric population, obesity and mental health problems are likely entwined, with each exerting cause and effect influences on the other [5]. Considering Western society's positive valuation of thinness, obese children often experience social rejection and victimization by peers, and have low quality of life indicators, low self-concept and poor self-perception [6-9]. Body image is a child's internal representation of their own outer appearance [6] whereas self-concept (also called self-esteem) is how a child feels about all the characteristics that make up his or her person, taking into account, among other things, skills and abilities, interactions with others, and physical self-image [10]. Low self-concept undermines a child's realization of their full human potential in a range of settings given that children who do not feel good about themselves and their abilities are prone to anxiety and depression [11].

If indigenous children have internalized the negative values and perceptions of the mainstream society about obesity, then obesity not only potentially predisposes indigenous children to chronic disease but is also a stigmatizing condition which can compromise children's mental wellbeing by threatening self-concept and creating body size dissatisfaction and poor body image [7-9]. Once selfconcept and body image are internalized they tend to remain stable, underlining the importance of efforts in childhood to protect them [7-9,11]. Research among indigenous children, as with other children, has often lacked an examination of these and other important psychosocial correlates of excess adiposity [8].

The objective of the present study was to provide an understanding of the association between adiposity and body size satisfaction, body image and self-concept in Cree First Nations schoolchildren living in the Province of Quebec in Canada. The remote communities where these children live are characterized by a high prevalence of obesity and obesity-associated chronic diseases such as type II diabetes mellitus [12,13]. Virtually no data exists about body size satisfaction or self-concept in indigenous children in Canada. The specific aims of the study were to examine the relationship between (a) weight status and physical appearance satisfaction using both pictorial and verbal body rating measures, and (b) adiposity and self-concept using a validated psychometric scale.

\section{Methods}

\section{Study population}

Data were from the Emiyuu Ayayaachiit Awaash (Active Kids) Project that gathered information on weight status, health behaviours (dietary intake and physical activity), diabetes awareness, self-concept and body size perceptions among children in grades 4 to 6 in two Cree communities (each with population $<3000$ persons) in northern Quebec. Data were collected in the fall of 2004 and 2005. The study was conducted in English (a language of instruction at school) with the assistance of a Cree interpreter. Results regarding child weight status (assessed using the International Obesity Task Force growth reference [14] or the US Centers for Disease Control growth charts [15]) and diabetes awareness, body size perception and lifestyle behaviors appear elsewhere [16-19].

All children provided verbal assent to a statement by the interviewer asking if they were willing to participate and their parents provided written informed consent for their child to participate. Ethics approval was received from the Human Research Ethics Board of the Faculty of Agriculture, Forestry and Home Economics at the University of Alberta. The study was approved by the school Principals and the Research Office of the Cree Board of Health and Social Services of James Bay (Quebec) which also reviewed the manuscript.

\section{Measures \\ Anthropometrics}

Height was measured at maximal inspiration using a set square and a standard tape measure, and weight using a portable electronic scale (Health-O-Meter Professional Scale; Model HAP300-01; Boca Raton, FL, USA). All measurements occurred in a private room with two researchers present. Children were dressed in light indoor clothing without shoes. Body mass index (BMI) was calculated to the nearest $0.01 \mathrm{~kg} / \mathrm{m}^{2}$. BMI $\mathrm{z}$-scores and weight status categories (normal weight, overweight but not obese, obese) were created according to the World Health Organization age- and gender-specific reference values [20].

\section{Pictorial and verbal measures of physical appearance satisfaction}

Three measures were used to assess children's physical appearance satisfaction in a classroom setting. Using a paper survey, children were asked 'What do you think of your body size?' where the response options were 'too big', 'too small' and 'just right'. For the question "Do you like the way you look now?" the response options were 'yes' or 'no'. Questions were read out loud to children, who then circled their responses. Culturally appropriate figures (line drawings) of eight American Indian boys and girls ranging in order from thin to obese were used to evaluate children's perceived and desired body size. [21]. Children selected the figure that represented their own body size and the figure that represented their ideal 
body size using the respective questions "Circle the figure that looks the most like you" and "Circle the figure that you want to look like". Girls chose from female figures and boys from male figures. To analyze responses, figures were numbered from one (smallest) to eight (largest). The discrepancy between the figures that children chose to represent their perceived and desired body sizes was used as a measure of body size satisfaction [22]. Children with no discrepancy between the two figures were considered to be 'ok' with their body size (i.e., to have body size satisfaction), children with positive discrepancy were considered to have a 'desire to be smaller', and children with negative discrepancy were considered to have a 'desire to be bigger'.

\section{Psychological self-concept}

Self-concept data was collected only in 2004. Children completed the Piers-Harris Children's Self-Concept Scale, 2nd edition (PHCSCS-2) [10]. PHCSCS-2 is a self-report questionnaire prompting yes/no answers to 25 positively and 35 negatively phrased items (e.g. 'I am smart'; 'My looks bother me'). It measures self-concept globally as well as in six domains: behavioral adjustment, intellectual and school status, physical appearance and attributes, freedom from anxiety, popularity, and happiness and satisfaction. Higher scores indicate a more positive self-evaluation in the domain being measured [10]. The physical appearance and attributes domain is similar to body image. It measures the child's appraisal of his or her physical appearance, as well as attributes such as leadership and the ability to express ideas. T-scores from the PHCSCS-2 of 40 to 60 represent the normal range for global self-concept and each of its domains [10].

\section{Statistical analysis}

The association between a child's weight status and each of the three physical appearance satisfaction measures was estimated in multivariate regression models that included child's age and sex. Separate models were fitted to the data for each outcome measure. Specifically, multinomial logistic regression models were fitted for body size dissatisfaction based on the discrepancy between the two figures ('ok' as the reference category) and responses to the question 'What do you think of your body size?'('just right' as the reference category). Logistic regression model was fitted for physical appearance satisfaction based on responses to the question "Do you like the way you look now?" ('yes' as the reference category).

For each child, raw scores for global self-concept and its six domains from the PHCSCS-2 were converted to

Table 1 Characteristics of children's weight status and physical appearance satisfaction ( $\mathrm{n}=202)$ and psychological well-being $(\mathbf{n}=\mathbf{7 8})$

\begin{tabular}{|c|c|c|c|c|}
\hline \multirow[b]{2}{*}{ Variable } & \multicolumn{2}{|c|}{ Full sample $(n=202)$} & \multicolumn{2}{|c|}{ Sub-sample $(n=78)$} \\
\hline & Mean & SD & Mean & SD \\
\hline Age, years & 10.67 & 0.98 & 10.85 & 1.03 \\
\hline $\mathrm{BMI}, \mathrm{kg} / \mathrm{m}^{2}$ & 23.05 & 5.07 & 23.86 & 5.52 \\
\hline \multirow[t]{2}{*}{ BMI z-score ${ }^{a}$} & 1.78 & 1.22 & 1.90 & 1.23 \\
\hline & $\mathbf{n}$ & $\%$ & $\mathrm{n}$ & $\%$ \\
\hline Girl & 114 & 56.44 & 50 & 64.10 \\
\hline Normal weight ${ }^{b}$ & 54 & 26.73 & 18 & 23.08 \\
\hline Overweight ${ }^{\mathrm{b}}$ & 57 & 28.22 & 22 & 28.21 \\
\hline Obese $^{b}$ & 91 & 45.05 & 38 & 48.72 \\
\hline \multicolumn{5}{|l|}{ Pictorial discrepancy } \\
\hline desire to be smaller & 128 & 63.37 & 60 & 76.92 \\
\hline ok with body size & 49 & 24.26 & 11 & 14.10 \\
\hline desire to be bigger & 25 & 12.38 & 7 & 8.97 \\
\hline \multicolumn{5}{|c|}{ What do you think of your body size? } \\
\hline too big & 59 & 29.21 & 29 & 37.18 \\
\hline just right & 122 & 60.40 & 45 & 57.69 \\
\hline too small & 21 & 10.40 & 4 & 5.13 \\
\hline \multicolumn{5}{|c|}{ Do you like the way you look now? } \\
\hline no & 70 & 34.65 & 36 & 46.15 \\
\hline yes & 132 & 65.35 & 42 & 53.85 \\
\hline
\end{tabular}

${ }^{\mathrm{a} B M I}$ z-scores according to the World Health Organization (WHO) age- and gender-specific reference values [20].

${ }^{b}$ Weight status categories (normal weight, overweight, and obese) according to the World Health Organization (WHO) age- and gender-specific reference values [20]. 
Table 2 Children's $(\mathbf{n}=\mathbf{7 8})$ self-concept scores and the prevalence of low, average and above average scores

\begin{tabular}{|c|c|c|c|c|}
\hline & \multirow{2}{*}{$\begin{array}{l}\text { Self concept } \\
\text { T-score } \\
\text { (Mean } \pm \text { SD) }\end{array}$} & \multicolumn{3}{|c|}{$\begin{array}{l}\text { Distribution of Self concept } \\
\text { T-scores }\end{array}$} \\
\hline & & $\begin{array}{c}\text { Low } \\
\text { range } \\
(\%)\end{array}$ & $\begin{array}{c}\text { Average } \\
\text { range } \\
(\%)\end{array}$ & $\begin{array}{c}\text { High } \\
\text { range } \\
(\%)\end{array}$ \\
\hline $\begin{array}{l}\text { Global Self } \\
\text { concept }\end{array}$ & $42.0 \pm 7.3$ & 40.0 & 58.0 & 1.3 \\
\hline \multicolumn{5}{|l|}{$\begin{array}{l}\text { Self-Concept } \\
\text { Domains }\end{array}$} \\
\hline $\begin{array}{l}\text { Physical } \\
\text { appearance and } \\
\text { attributes }\end{array}$ & $39.8 \pm 7.0$ & 46.3 & 51.3 & 2.5 \\
\hline Popularity & $42.1 \pm 7.1$ & 35.0 & 63.8 & 1.3 \\
\hline $\begin{array}{l}\text { Happiness and } \\
\text { satisfaction }\end{array}$ & $43.2 \pm 7.6$ & 33.8 & 58.8 & 7.5 \\
\hline $\begin{array}{l}\text { Freedom from } \\
\text { anxiety }\end{array}$ & $44.6 \pm 8.2$ & 30.0 & 60.0 & 10.0 \\
\hline $\begin{array}{l}\text { Behavioral } \\
\text { adjustment }\end{array}$ & $44.7 \pm 7.2$ & 26.3 & 68.8 & 5.0 \\
\hline $\begin{array}{l}\text { Intellectual and } \\
\text { school status }\end{array}$ & $45.2 \pm 7.9$ & 22.5 & 68.8 & 8.8 \\
\hline
\end{tabular}

standardized t-scores. The association between child's BMI z-score and t-scores for global self-concept and its six domains were estimated using separate multivariate linear regression models that included child's age and sex.
Given the smaller sample of children who completed the PHCSCS-2 BMI z-score was chosen over weight status in the models. In our sensitivity models (results not shown), the multivariate regression models also included physical activity (mean step count from pedometers worn for three consecutive days) and dietary factors (mean daily calories consumed over three consecutive days, number of fruits and vegetables consumed each day, etc.). Additional analyses also included models with interaction terms for sex and weight status to formally test sex differences in these associations. Since results remained robust across all these sensitivity models and interaction terms for sex and weight status were not statistically significant, we present results from the most parsimonious models based on the largest sample size. All analyses were carried out using Stata Version 11, College Station, TX, USA.

\section{Results}

Of the 263 children in grades four to six in both communities, 202 (76.8\%) participated in the study and had parental consent for their data to be used. Of the 151 students participating in 2004, 105 (69.5\%) completed the PHCSCS-2; however, self-concept data are only reported for the 78 children without evidence of response bias (i.e., a tendency to respond yes or no irrespective of item content) or response inconsistency (i.e., random response patterns) in their answers [10]. These 78 children did not differ from the full sample $(n=202)$ in terms of their BMI or weight status.

Characteristics of children and their physical appearance satisfaction are in Table 1 . The majority was

Table 3 Odds ratios (SE) from regression models for physical appearance dissatisfaction $(\mathbf{n}=\mathbf{2 0 2})$

\begin{tabular}{|c|c|c|c|c|c|c|c|c|c|}
\hline \multirow{4}{*}{ Variable } & \multicolumn{3}{|c|}{ Model 1} & \multicolumn{3}{|c|}{ Model 2} & \multicolumn{3}{|c|}{ Model 3} \\
\hline & \multicolumn{3}{|c|}{ Pictorial discrepancy } & \multicolumn{3}{|c|}{ Think of your body size } & \multicolumn{3}{|c|}{ Like the way you look } \\
\hline & $\mathrm{OR}^{\mathrm{a}}$ & SE & p-value & $O^{a}$ & SE & p-value & $\mathrm{OR}^{\mathrm{b}}$ & SE & p-value \\
\hline & \multicolumn{3}{|c|}{ desire to be smaller vs. ok } & \multicolumn{3}{|c|}{ too big vs. just right } & \multicolumn{3}{|c|}{ no vs. yes } \\
\hline Normal weight $^{c}$ & Ref. & & & Ref. & & & Ref. & & \\
\hline Overweight $^{c}$ & 4.26 & $(2.11)$ & 0.00 & 7.72 & (6.34) & 0.01 & 2.45 & $(1.25)$ & 0.08 \\
\hline Obese $^{c}$ & 19.82 & $(10.70)$ & 0.00 & 30.61 & $(24.27)$ & 0.00 & 7.79 & $(3.64)$ & 0.00 \\
\hline Boy & Ref. & & & Ref. & & & Ref. & & \\
\hline Girl & 4.25 & $(1.76)$ & 0.00 & 1.88 & $(0.72)$ & 0.10 & 2.32 & $(0.80)$ & 0.02 \\
\hline \multirow[t]{2}{*}{ Age (years) } & 1.29 & $(0.26)$ & 0.21 & 2.26 & $(0.47)$ & 0.00 & 1.84 & $(0.33)$ & 0.00 \\
\hline & \multicolumn{3}{|c|}{ desire to be bigger vs. ok } & \multicolumn{3}{|c|}{ too small vs. just right } & \multicolumn{3}{|c|}{$n / a$} \\
\hline Normal weight ${ }^{c}$ & Ref. & & & Ref. & & & & & \\
\hline Overweight $^{c}$ & 0.31 & $(0.19)$ & 0.06 & 0.20 & $(0.12)$ & 0.01 & & & \\
\hline Obese ${ }^{c}$ & 0.10 & $(0.11)$ & 0.04 & 0.09 & $(0.07)$ & 0.00 & & & \\
\hline Boy & Ref. & & & Ref. & & & & & \\
\hline Girl & 1.54 & $(0.84)$ & 0.43 & 0.46 & $(0.24)$ & 0.14 & & & \\
\hline Age (years) & 0.42 & $(0.13)$ & 0.00 & 0.66 & $(0.18)$ & 0.13 & & & \\
\hline
\end{tabular}

a Odds ratios (OR) from multinomial logistic regression models (see Methods).

b Odds ratios (OR) from logistic regression models (see Methods).

${ }^{\mathrm{c}}$ Weight status categories (normal weight, overweight, and obese) according to the World Health Organization age- and gender-specific reference values [20]. 
overweight or obese. Children in the three weight classes did not differ significantly by age or gender. Results of the PHCSCS-2 are in Table 2. Many children had low scores indicating negative self-evaluation in the domain being measured, particularly for the physical appearance and attributes domain.

Results from three multivariate regression models of physical appearance satisfaction based on pictorial/verbal indicators from the full sample are in Table 3. Child's weight status was significantly and positively associated with all three indicators. Compared to normal weight children, overweight and obese children were more likely to desire to be smaller based on line drawings $(\mathrm{OR}=4.3$ and 19.8 , respectively), indicate their body size was too big (OR=7.7 and 30.6, respectively) and not like the way they looked ( $\mathrm{OR}=2.5$ and 7.8 , respectively). There were also differences in physical appearance satisfaction across child's gender and age. Girls were more likely to desire to be smaller than boys $(\mathrm{OR}=4.3)$, and to not like the way they look $(\mathrm{OR}=2.3)$. A child's likelihood of indicating their body size was too big and not liking the way they look increased with each year of age $(\mathrm{OR}=2.3$ and 1.8 , respectively).

Results from multivariate regression models of psychological well-being using PHCSCS-2 in the sub-sample of 78 participants are in Table 4. BMI z-score was significantly associated with lower $\mathrm{t}$-scores for global selfconcept $(\beta=-1.3)$, intellectual and school status $(\beta=-1.5)$, and physical appearance and attributes $(\beta=-1.3)$. Girls were more likely to have lower scores than boys for global self-concept $(\beta=-3.8)$, and physical appearance and attributes $(\beta=-4.2)$. Being older was associated with lower scores for physical appearance and attributes $(\beta=-1.5)$.

\section{Discussion}

This study found that higher levels of adiposity among Cree elementary school children were associated with physical appearance dissatisfaction (i.e., children wanting to be smaller, thinking their body size was too big, and not liking the way they looked) based on both verbal and pictorial measures and low scores on the physical appearance and attributes domain of self-concept indicating poor self-esteem in relation to body image and physical strength, feeling unattractive, or being bothered by specific aspects of physical appearance [10]. These findings are concerning given that children who are unhappy with their appearance whether due to weightrelated social pressures or personal weight concerns are prone to disordered eating and less likely to adopt health behaviors than children who have a positive sense of their bodies [8]. Children with greater adiposity also had lower scores for global self-concept and the intellectual and school domain of self-concept. Children with low global self-concept have doubts about their self-worth, lack confidence, and view themselves as being unpopular, having difficulty making friends and having poor relationships with family members. Children with low intellectual and school status have numerous perceived difficulties on specific schoolrelated tasks [10].

\section{Table 4 Coefficients (SE) from regression models for self-concept measured using Piers-Harris Self-Concept Scale (2nd edition) $(n=78)$}

\begin{tabular}{|c|c|c|c|}
\hline \multirow[t]{2}{*}{ Variable } & Coeff. $^{a}$ & SE & $\mathrm{p}$-value \\
\hline & \multicolumn{3}{|c|}{ Global Self-Concept } \\
\hline BMl z-score ${ }^{b}$ & -1.31 & $(0.65)$ & 0.05 \\
\hline Boy & Ref. & & \\
\hline Girl & -3.78 & $(1.75)$ & 0.03 \\
\hline \multirow[t]{2}{*}{ Age (years) } & 0.02 & $(0.82)$ & 0.99 \\
\hline & \multicolumn{3}{|c|}{ Behavioural adjustment } \\
\hline BMl z-score ${ }^{b}$ & -0.66 & $(0.67)$ & 0.33 \\
\hline Boy & Ref. & & \\
\hline Girl & 0.52 & $(1.80)$ & 0.77 \\
\hline \multirow[t]{2}{*}{ Age (years) } & 0.55 & $(0.84)$ & 0.51 \\
\hline & \multicolumn{3}{|c|}{ Intellectual and school status } \\
\hline BMI z-score ${ }^{b}$ & -1.46 & $(0.70)$ & 0.04 \\
\hline Boy & Ref. & & \\
\hline Girl & -3.43 & $(1.88)$ & 0.07 \\
\hline \multirow[t]{2}{*}{ Age (years) } & -0.54 & $(0.88)$ & 0.54 \\
\hline & \multicolumn{3}{|c|}{ Physical appearance and attributes } \\
\hline BMl z-score ${ }^{b}$ & -1.30 & $(0.59)$ & 0.03 \\
\hline Boy & Ref. & & \\
\hline Girl & -4.15 & $(1.57)$ & 0.01 \\
\hline \multirow[t]{2}{*}{ Age (years) } & -1.53 & (0.73) & 0.04 \\
\hline & \multicolumn{3}{|c|}{ Freedom from anxiety } \\
\hline BMl z-score ${ }^{b}$ & -0.97 & $(0.75)$ & 0.20 \\
\hline Boy & Ref. & & \\
\hline Girl & -3.55 & $(2.00)$ & 0.08 \\
\hline \multirow[t]{2}{*}{ Age (years) } & -0.13 & (0.93) & 0.89 \\
\hline & \multicolumn{3}{|c|}{ Popularity } \\
\hline BMI z-score ${ }^{b}$ & -0.35 & $(0.66)$ & 0.60 \\
\hline Boy & Ref. & & \\
\hline Girl & -1.32 & (1.78) & 0.46 \\
\hline \multirow[t]{2}{*}{ Age (years) } & 0.30 & $(0.83)$ & 0.72 \\
\hline & \multicolumn{3}{|c|}{ Happiness and satisfaction } \\
\hline BMl z-score ${ }^{b}$ & -1.32 & $(0.69)$ & 0.06 \\
\hline Boy & Ref. & & \\
\hline Girl & -2.40 & $(1.85)$ & 0.20 \\
\hline Age (years) & -0.32 & $(0.86)$ & 0.71 \\
\hline
\end{tabular}

Abbreviations: BMI, body mass index $\left(\mathrm{kg} / \mathrm{m}^{2}\right)$.

${ }^{a}$ Coefficients from multivariate linear regression models (see Methods).

b BMI z-scores according to the World Health Organization age- and genderspecific reference values [20]. 
The findings suggest that Cree children have internalized the broader societal message that thin is better and physical appearance is an important evaluative component of the self [7]. Even in remote areas of North America, children receive communications through forms of mass media such as television and the internet that influence their beliefs and attitudes about what is a healthy and optimal body size [22,23]. Cree girls had more physical appearance dissatisfaction and lower selfconcept than boys despite having a similar weight status. This finding suggests girls had greater internalization of societal messages about a desirable weight or were subjected to a greater degree of criticism about their weight [22].

Strengths of this study were that children were classified into weight categories using measured rather than self-reported heights and weights. The use of ethnically appropriate line drawings to measure body size satisfaction likely allowed children to identify with the figures and choose the best response to the questions about actual and desired body size. We used a validated multidimensional measure of self-concept, and corroborated findings using multiple assessments that served to complement and provide independent verification of self-concept [11]. Limitations were the study's crosssectional design meaning the causal process between obesity and self-concept could not be discerned. Longitudinal studies are required to elucidate the nature of the relationship. Interpretation of the PHCSCS-2 may be problematic in this population. The validity of the scale with Cree children is unknown given that the normative sample was different from the children in the present study and cultural response styles can influence test results [10].

\section{Conclusions}

There are efforts across Canada to inform First Nations people about the health risks of excess weight including the development of type 2 diabetes mellitus [1,24]. Given Cree children's disposition for low self-concept, poor body image and body size dissatisfaction, obesity prevention efforts in Cree and other indigenous children must be cautious in their approach and take into account mental and emotional aspects of children's well-being. When counseling about the importance of a healthy body weight care should be taken to focus on health promoting behaviors rather than solely weight loss to avoid increasing body size dissatisfaction and undermining self-worth. Although controversial, one such strategy would be the Health at Every Size (http://www.haescommunity.org/) approach which focuses on children adopting health habits for the sake of health and well-being rather than weight control [25]. It is a model which seeks to avoid the known psychological harm of stigmatizing obesity. Future obesity research in indigenous children must include a greater understanding of how obesity is perceived and its potential impact on mental wellbeing.

\section{Abbreviations}

BMI: Body mass index; PHCSCS-2: Piers-Harris children's self-concept scale, 2nd edition; OR: Odd ratio; SE: Standard error

\section{Competing interests}

The authors declare that they have no competing interests.

\section{Authors' contributions}

NDW and KM contributed to data analysis and interpretation. DR was responsible for data collection and data entry. KDR and DR assisted with the original research design. NDW wrote the manuscript draft. All authors read and approved the final manuscript.

\section{Acknowledgements}

This research was funded by a grant from the Canadian Institutes of Health Research. NDW received salary support during the time of the research from Population Health Investigator and Health Scholar Awards from the Alberta Heritage Foundation for Medical Research (Alberta Innovates Health Solutions).

\section{Author details}

'Department of Agricultural, Food and Nutritional Science, University of Alberta, Edmonton, Canada. ${ }^{2}$ Centre for Health Promotion Studies, University of Alberta, Edmonton, Canada. ${ }^{3}$ School of Public Health, University of Alberta, Edmonton, Canada.

Received: 21 May 2013 Accepted: 8 August 2013

Published: 12 August 2013

\section{References}

1. Willows ND, Hanley AJG, Delormier T: A socioecological framework to understand weight-related issues in Aboriginal children in Canada. Appl Physiol Nutr Metab 2012, 37:1-13.

2. Strauss K: Evidence-based public health responses to the overweight crisis in American Indian and Alaska Native communities. IHS Prim Care Provider 2010, 35:116-122.

3. Sarche MC, Spicer P, Farrell P, Fitzgerald HE: American Indian and Alaska Native children and mental health: development, context, prevention, and treatment. Santa Barbara: Praeger; 2011.

4. Kirmayer $\sqcup$, Valaskakis GG: Healing traditions: the mental health of Aboriginal Peoples in Canada. Vancouver: University of British Columbia Press; 2008.

5. Collingwood J: Obesity and Mental Health. Psych Central 2007. Retrieved on May 14, 2013, from http://psychcentral.com/lib/2007/obesity-andmental-health/.

6. Smolak L, Thompson JK: Body image, eating disorders, and obesity in youth: assessment, prevention, and treatment. 2nd edition. Washington DC: American Psychological Association; 2008.

7. Griffiths LJ, Parsons TJ, Hill AJ: Self-esteem and quality of life in obese children and adolescents: a systematic review. Int J Pediatr Obes 2010, 5:282-304

8. Russell-Mayhew S, McVey G, Bardick A, Ireland A: Mental health, wellness, and childhood overweight/obesity. J Obes 2012, 2012:281801. doi:10.1155/ 2012/281801.

9. Mustillo SA, Hendrix KL, Schafer MH: Trajectories of body mass and self-concept in black and white girls: the lingering effects of stigma. $J$ Health Soc Behav 2012, 53:2-16.

10. Piers EV, Herzberg DS: Piers-Harris 2: Piers-Harris Children's Self-Concept Scale. 2nd edition. Los Angeles: Western Psychological Services; 2003.

11. Craven RG, Marsh HW: The centrality of the self-concept construct for psychological wellbeing and unlocking human potential: implications for child and educational psychologists. Educ Child Psychol 2008, 25:104-118.

12. Khalii CB, Johnson-Down L, Egeland GM: Emerging obesity and dietary habits among James Bay Cree youth. Public Health Nutr 2010, 13:1829-37.

13. Chateau-Degat ML, Dannenbaum DA, Egeland GM, Nieboer E, Laouan Sidi EA, Abdous B, Dewailly É: A comparison of the metabolic response to abdominal obesity in two Canadian Inuit and First Nations population. Obesity 2011, 19:2254-60. 
14. Cole TJ, Bellizzi MC, Flegal KM, Dietz WH: Establishing a standard definition for child overweight and obesity worldwide: international survey. BMJ 2000, 320:1240-1243.

15. Kuczmarski RJ, Ogden CL, Guo SS, Grummer-Strawn LM, Flegal KM, Mei Z, Wei R, Curtin LR, Roche AF, Johnson CL: CDC growth charts for the United States: Methods and development. Vital Health Stat 2000, 2002(11):1-190.

16. Ng C, Marshall D, Willows ND: Obesity, adiposity, physical fitness and activity levels in Cree children. Int I Circumpolar Health 2006, 65:221-229.

17. Downs S, Marshall D, Ng C, Willows ND: Central adiposity and associated lifestyle factors in Cree schoolchildren. Appl Physiol Nutr Metab 2008, 33:476-482

18. Downs SM, Arnold A, Marshall D, McCargar LJ, Raine KD, Willows ND: Associations among the food environment, diet quality and weight status in Cree children in Québec. Public Health Nutr 2009, 12:1504-1511.

19. Willows ND, Marshall D, Raine K, Ridley DC: Diabetes awareness and body size perceptions of Cree schoolchildren. Health Educ Res 2009, 24:1051-1058.

20. De Onis M, Onyango AW, Borghi E, Siyam A, Nishida C, Siekmann J: Development of a WHO growth reference for school-aged children and adolescents. Bull World Health Organ 2007, 85:660-667.

21. Stevens J, Story M, Becenti A, French SA, Gittelsohn J, Going SB, Juhaeri, Levin S, Murray DM: Weight related attitudes and behaviors in fourth grade American Indian children. Obes Res 1999, 7:34-42.

22. Davis $S M$, Lambert $L C$ : Body image and weight concerns among Southwestern American Indian preadolescent schoolchildren. Ethn Dis 2000, 10:184-194.

23. Gittelsohn J, Harris S, Thorne-Lyman A, Hanley A, Barnie A, Zinman B: Body image concepts differ by age and sex in an Ojibway-Cree community in Canada. J Nutr 1996, 126:2990-3000.

24. Pigford AE, Willows ND: Promoting optimal weights in Aboriginal children in Canada through ecological research. In Childhood Obesity Prevention: International Research, Controversies and Interventions. Edited by O'Dea JA, Eriksen M. New York: Oxford University Press; 2010:309-320.

25. Bacon L, Aphramor L: Weight Science: evaluating the evidence for a paradigm shift. Nutrition J 2011, 10:9. doi:10.1186/1475-2891-10-9.

doi:10.1186/1471-2431-13-118

Cite this article as: Willows et al:: High adiposity is associated cross-sectionally with low self-concept and body size dissatisfaction among indigenous Cree schoolchildren in Canada. BMC Pediatrics 2013 13:118

\section{Submit your next manuscript to BioMed Central and take full advantage of:}

- Convenient online submission

- Thorough peer review

- No space constraints or color figure charges

- Immediate publication on acceptance

- Inclusion in PubMed, CAS, Scopus and Google Scholar

- Research which is freely available for redistribution 